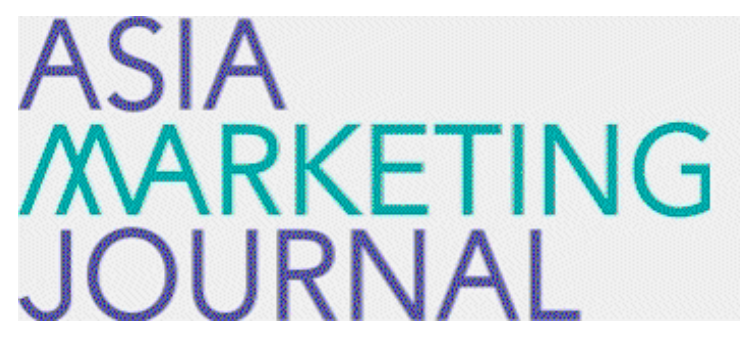

ASIA MARKETING JOURNAL

Volume 20 | Issue 4

Article 5

$1-31-2019$

\title{
ASIA MARKETING JOURNAL Vol.20 No.4 목차
}

Follow this and additional works at: https://amj.kma.re.kr/journal

Part of the Marketing Commons

\section{Recommended Citation}

(2019) "ASIA MARKETING JOURNAL Vol.20 No.4 목차," Asia Marketing Journal: Vol. 20 : Iss. 4 , Article 5. Available at: https://doi.org/10.53728/2765-6500.1324

This Article is brought to you for free and open access by Asia Marketing Journal. It has been accepted for inclusion in Asia Marketing Journal by an authorized editor of Asia Marketing Journal. 


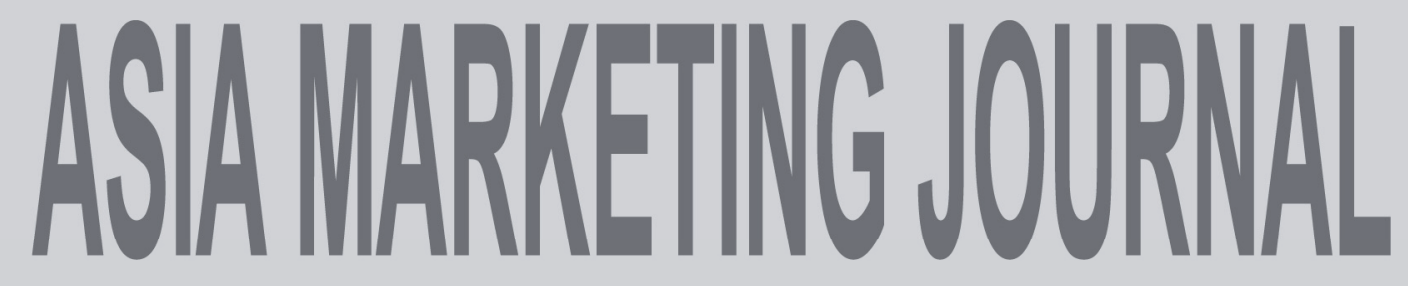

\section{Vol. 20 No. 04 January 2019}

\section{$<$ Research Paper>}

Pioneering New Markets: A Case study of SevenBräu

Shijin Yoo $\cdot$ Myung Soo Kang $\cdot$ Minjeong Kim

1

The Synergy Effect of a Corporate-Level Loyalty Program Integration

on Customer Equity

Dae-Yun Park · Shijin Yoo

You Want More When You Have Something in Your Hand

Labeling and Customer Loyalty: Mediating Effects of Brand-related Constructs

Zheltauova Gulzira · Sang-Lin Han 